\title{
L--N-methylamino-L-alanine (BMAA) nitrosation generates a cytotoxic DNA damaging alkylating agent: An unexplored mechanism for neurodegenerative disease
}

DOI:

10.1016/j.neuro.2017.01.007

\section{Document Version}

Accepted author manuscript

Link to publication record in Manchester Research Explorer

Citation for published version (APA):

Potjewyd, G., Day, P., Shangula, S., Margison, G., \& Povey, A. (2017). L--N-methylamino-L-alanine (BMAA) nitrosation generates a cytotoxic DNA damaging alkylating agent: An unexplored mechanism for neurodegenerative disease. NeuroToxicology. https://doi.org/10.1016/j.neuro.2017.01.007

\section{Published in:}

NeuroToxicology

\section{Citing this paper}

Please note that where the full-text provided on Manchester Research Explorer is the Author Accepted Manuscript or Proof version this may differ from the final Published version. If citing, it is advised that you check and use the publisher's definitive version.

\section{General rights}

Copyright and moral rights for the publications made accessible in the Research Explorer are retained by the authors and/or other copyright owners and it is a condition of accessing publications that users recognise and abide by the legal requirements associated with these rights.

\section{Takedown policy}

If you believe that this document breaches copyright please refer to the University of Manchester's Takedown Procedures [http://man.ac.uk/04Y6Bo] or contact uml.scholarlycommunications@manchester.ac.uk providing relevant details, so we can investigate your claim.

\section{OPEN ACCESS}




\section{Accepted Manuscript}

Title: L- $\beta$-N-methylamino-L-alanine (BMAA) nitrosation generates a cytotoxic DNA damaging alkylating agent: An unexplored mechanism for neurodegenerative disease

Authors: G. Potjewyd, P.J. Day, S. Shangula, G.P. Margison,

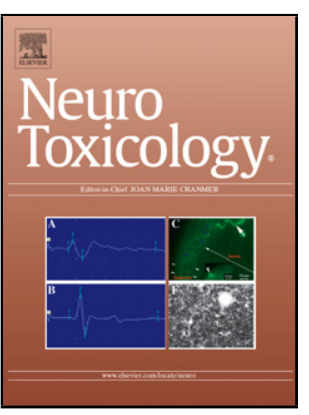
A.C. Povey

PII: S0161-813X(17)30018-9

DOI: http://dx.doi.org/doi:10.1016/j.neuro.2017.01.007

Reference: NEUTOX 2132

To appear in: NEUTOX

Received date: 27-9-2016

Revised date: 26-1-2017

Accepted date: 26-1-2017

Please cite this article as: Potjewyd G, Day PJ, Shangula S, Margison GP, Povey A.C.L- $\beta-N-$ methylamino-L-alanine (BMAA) nitrosation generates a cytotoxic DNA damaging alkylating agent: An unexplored mechanism for neurodegenerative disease.Neurotoxicology http://dx.doi.org/10.1016/j.neuro.2017.01.007

This is a PDF file of an unedited manuscript that has been accepted for publication. As a service to our customers we are providing this early version of the manuscript. The manuscript will undergo copyediting, typesetting, and review of the resulting proof before it is published in its final form. Please note that during the production process errors may be discovered which could affect the content, and all legal disclaimers that apply to the journal pertain. 
L- $\beta$-N-methylamino-L-alanine (BMAA) nitrosation generates a cytotoxic DNA damaging alkylating agent: an unexplored mechanism for neurodegenerative disease.

Potjewyd $\mathrm{G}^{1}$, Day $\mathrm{PJ}^{1,2}$, Shangula $\mathrm{S}^{1}$, Margison $\mathrm{GP}^{1}$, Povey $\mathrm{AC}^{1}$

${ }^{1}$ Centre for Epidemiology, School of Health Sciences, Faculty of Biology, Medicine and Health, University of Manchester, Manchester, UK.

${ }^{2}$ Manchester Institute for Biotechnology, University of Manchester, Manchester, UK.

Correspondence to Dr AC Povey, Centre for Occupational and Environmental Health, School of Health Sciences, Faculty of Biology, Medicine and Health, Ellen Wilkinson Building, University of Manchester, M13 9PH. (apovey@manchester.ac.uk)

Highlights (Potjewyd et al)

- A novel mechanism of L- $\beta-\mathrm{N}$-methylamino-L-alanine (BMAA) toxicity is proposed.

- N-Nitrosation of BMAA results in an alkylating agent that causes DNA strand breaks.

- Nitrosated BMAA is toxic to the human neuroblastoma cell line SH-SY5Y.

- Endogenous nitrosation of BMAA may help to cause neurodegenerative disease 


\section{Abstract}

Background

$\mathrm{L}-\beta-\mathrm{N}-\mathrm{methylamino-L-alanine} \mathrm{(BMAA)} \mathrm{is} \mathrm{a} \mathrm{non-proteinic} \mathrm{amino} \mathrm{acid,} \mathrm{that} \mathrm{is} \mathrm{neurotoxic} \mathrm{in} \mathrm{vitro} \mathrm{and} \mathrm{in}$ animals, and is implicated in the causation of amyotrophic lateral sclerosis and parkinsonismdementia complex (ALS-PDC) on Guam. Given that natural amino acids can be $N$-nitrosated to form toxic alkylating agents and the structural similarity of BMAA to other amino acids, our hypothesis was that $N$-nitrosation of BMAA might result in a toxic alkylating agent, providing a novel mechanistic hypothesis for BMAA action.

\section{Findings}

We have chemically nitrosated BMAA with sodium nitrite to produce nitrosated BMAA (N-BMAA) which was shown to react with the alkyl-trapping agent, 4-(p-nitrobenzyl)pyridine, cause DNA strand breaks in vitro and was toxic to the human neuroblastoma cell line SH-SY5Y under conditions in which BMAA itself was minimally toxic.

\section{Conclusions}

Our results indicate that $N$-BMAA is an alkylating agent and toxin suggesting a plausible and previously unrecognised mechanism for the neurotoxic effects of BMAA.

Keywords: BMAA, ALS, Alkylating agent, $N$-nitrosation

\section{Introduction}


$\beta$-methylamino-L-alanine (BMAA) exposure has long been associated with neurodegenerative diseases, particularly on Guam where high rates of amyotrophic lateral sclerosis (ALS) and Parkinson's disease-like dementia complex (ALS-PDC) have been reported [1,2]. Such conditions have been linked to consumption of foodstuffs with high BMAA levels, typically flying foxes and other animals that bioaccumulate BMAA in their tissues as a result of eating cycad seeds $[2,3]$. The increasing westernisation of the diet on Guam has decreased consumption of these BMAA rich dietary sources and this has been linked to decreases in the incidence of ALS and ALS-PDC on Guam [4]. These observations are consistent with BMAA being neurotoxic in humans. BMAA is present in cycad seeds through synthesis by symbiotic cyanobacteria. While numerous cyanobacteria species can produce BMAA [5], it is currently unclear to what extent humans may be exposed e.g. via cyanobacterial blooms [6]. However, BMAA has been found in the brains of ALS and other patients not only from Guam but also North America and this does suggest a more widespread exposure than initially considered $[7,8]$.

In vitro studies have shown that BMAA is toxic to neurons $[9,10]$. BMAA can react with bicarbonate ions to form a $\beta$-carbamate that is a structural analogue of glutamate and hence can bind to various glutamate receptors including the $N$-methyl-D-aspartate and $\alpha$-amino-3-hydroxy-5-methyl-4isoxazolepropionic acid receptors leading to excitotoxicity. Receptor activation leads to a chain of events that involves increased concentrations of intracellular $\mathrm{Na}^{+}$and $\mathrm{Ca}^{2+}$ and decreased $\mathrm{K}^{+}$levels, altered membrane permeability, mitochondrial dysfunction and increased reactive oxygen species (ROS) production, and ultimately leads to cell death $[9,10]$. BMAA can also act as a substitute for Lserine and be incorporated into human [11], though not bacterial proteins [12] nor proteins obtained from the brains of BMAA treated cynomologus monkeys [13]. 
BMAA incorporated into proteins can cause protein misfolding and aggregation [11] a process often linked to neurodegenerative disease [14]. Furthermore, protein-bound BMAA may act as a reservoir that releases free BMAA as proteins are degraded [15].

Numerous In vivo studies have shown that high dose acute and chronic BMAA exposure can have neurotoxic effects that are typically motor function deficits $[9,16,17]$. For example, a motor system disorder, similar to ALS/PDC was observed in macaques treated with between 0.1-0.3 g/BMAA/kg/day by gavage for up to 12 weeks [18]. These doses may be much higher than would be observed in human populations [19], and so the association between BMAA and ALS/PDC remains controversial. In addition, the cycad nut also contains cycasin, whose active metabolite, methylazoxymethanol (MAM) is toxic to neurons and can affect brain development in experimental animal models $[20,21]$ with DNA repair inhibition resulting in more pronounced effects suggesting a DNA damage mediated mechanism [20,21]. MAM is a methylating agent, one of a class of agents that is toxic, mutagenic and carcinogenic largely as a result of the formation of specific methylated nucleobase adducts [22]. Interestingly DNA alkylating agents can also be formed by the $N$-nitrosation of natural amino acids $[23,24]$ and hence may have similar properties to MAM.

Given the structural similarity of BMAA to other amino acids, our hypothesis was that $N$-nitrosation of BMAA might result in a toxic alkylating agent, providing a previously unrecognised mechanism for BMAA action. 


\section{Materials and methods}

\section{Materials}

Unless otherwise stated, all materials, reagents and chemicals were purchased from Sigma-Aldrich (Gillingham, UK). Agarose, molecular grade crystalline powder was purchased from Bioline, UK, gel red nucleic acid stain from Biotium, UK and sodium hydroxide from Fisher Scientific, UK. SH-SY5Y, a human neuroblastoma cell line, was obtained from the Professor Doig (University of Manchester) at passage 10 and were cultured in Dulbecco's Modified Eagle's Medium (DMEM) with 10\% (v/v) foetal bovine serum (FBS), $1 \%(\mathrm{w} / \mathrm{v})$ glutamine, $10 \mathrm{~mL} / \mathrm{L}$ of solution containing $10,000 \mathrm{U}$ penicillin-G and 10 $\mathrm{mg}$ streptomycin $/ \mathrm{ml}$, and in a humidified incubator with gas mixture $95 \%$ air $/ 5 \% \mathrm{CO} 2(\mathrm{v} / \mathrm{v})$ at $37^{\circ} \mathrm{C}$. Cells were subcultured every 3-4 days when they had reached approximately $80 \%$ confluency and were discarded after passage 20. The plasmid nicking assay used a pUC8-based plasmid (pchAT 3319 bp) that was extracted from exponentially growing $E$. coli (strain DH5alpha). Amino acids were $\mathrm{N}$ nitrosated by incubation with sodium nitrite $(1 \mathrm{M})$ at $37^{\circ} \mathrm{C}$ for $1 \mathrm{hr}$ in sodium citrate buffer $(\mathrm{pH} 2.1)$ either simultaneously with [25] or immediately before the subsequent experimental procedure [24].

\section{4-P-Nitrobenzyl Pyridine (NBP) trapping assay}

The alkylating potency of BMAA, after nitrosation with sodium nitrite (nitrosated BMAA or N-BMAA) was assessed using the NBP trapping assay and presented as increases in absorbance at $595 \mathrm{~nm}$. Varying concentrations $(20,40,60,80 \mathrm{mM})$ BMAA or $\alpha$-alanine (positive control), $\mathrm{NaNO}_{2}(200 \mathrm{mM})$, NBP $(24 \mathrm{mM})$, and citrate buffer $(550 \mathrm{mM}, \mathrm{pH} 2.1)$ were incubated for 60 minutes at $37^{\circ} \mathrm{C}$ then a $\mathrm{NaOH}$ /acetonitrile colour development reagent $(4 \mathrm{~mL} 1 \mathrm{M} \mathrm{NaOH} ; 20 \mathrm{~mL}$ acetonitrile; $10.8 \mathrm{~mL}$ water) added to stop the alkylation reaction and basify the NBP-amino acid adducts to form a blue product. Immediately afterwards, absorbance measurements at $595 \mathrm{~nm}$ were obtained using a Tecan Genios microtitre plate reader. Negative controls were the nitrosation mix without the amino acid, the amino acids and nitrosation mix without the colour development reagent, the amino acids and the 
colour development reagent without the sodium nitrite and the amino acids without the nitrosation mix.

\section{Plasmid nicking assay}

The extent of DNA strand break formation following treatment with $N$-BMAA and BMAA was assessed using a plasmid nicking assay. N-BMAA \& BMAA (1-7mM) and phosphate buffer (pH 7.0) were incubated with 10ng pchAT plasmid DNA for 3 hours at $37^{\circ} \mathrm{C}$. Post incubation, $8 \mu \mathrm{L}$ of incubated plasmid mix was mixed with $2 \mu \mathrm{L}$ of loading dye $(10 \mathrm{mMTris} \mathrm{HCl} \mathrm{pH} 7.5,0.4 \% \mathrm{w} / \mathrm{v}$ orange $\mathrm{G}, 0.03 \%$ of w/v bromophenol blue, 0.03\% w/v xylene cyanol FF, 15\% Ficoll 400 and $50 \mathrm{mM}$ EDTA) and loaded onto an agarose gel $(1 \% \mathrm{w} / \mathrm{v})$ prepared in TBE containing $5 \mu \mathrm{L}$ of Gel Red. Gel electrophoresis was performed in TBE containing $50 \mu \mathrm{L} / \mathrm{L}$ Gel Red using at $100 \mathrm{mV}$ for 30 minutes. Gels were scanned using a Typhoon Phosphorimager using the preset settings for Alexafluor Fluorescence). Image J software was used to quantify the supercoiled and the nicked bands and results expressed the fraction of plasmid that was nicked. Alanine and nitrosated alanine were similarly treated. The positive control was the plasmid treated with a Fenton's reaction mix containing $\mathrm{FeSO}_{4}$ and $\mathrm{H}_{2} \mathrm{O}_{2}$ in a Tris buffer and the negative controls the plasmid treated with or without nitrite.

\section{Cellular Toxicity}

Cell toxicity of N-BMAA and BMAA was assessed in SH-SY5Y cells using a fluorimetric resazurin assay. SH-SY5Y cells were plated (10,000 per well) on 96 -well plates and incubated for 24,48 , and 96 hours after the addition of $\mathrm{N}$-BMAA (as prepared for the acellular assays using $\mathrm{NaNO}_{2}$ in citrate buffer) and BMAA $(0.5-4 \mathrm{mM})$. After these periods, $0.005 \%(\mathrm{w} / \mathrm{v})$ resazurin was added to the wells and the samples further incubated for 6 hours. Sodium chloride [5M] was used as a positive control to induce cell death. The nitrosation mix $\left(\mathrm{NaNO}_{2} /\right.$ citrate) was used as the negative control. 


\section{Results and Discussion}

We first examined whether chemical nitrosation of BMAA with sodium nitrite resulted in the formation of an alkylating agent by using the NBP trapping assay [25-27]. We used conditions where the amino acid nitrosation and NBP alkylation were present simultaneously, in order to ensure the detection of labile intermediates $[25,26]$. NBP-adduct formation was dose-dependent and N-BMAA proved to be a more potent alkylating agent than nitrosated alanine, based upon the response obtained with similar amounts of amino acid present in the nitrosation mix (Figure 1). BMAA or alanine alone did not react with NBP (data not shown). The NBP assay has been widely used as a screening assay to detect the alkylating potency of many compounds, [23-27] by the formation of adducts at the nucleophilic N4 position on NBP [27]. Since the N4 has similar physicochemical properties to the N7 of guanine, a favourable site of alkylation [28] this provided the initial indication that $N$-nitrosated BMAA was likely to be a DNA damaging agent.

To further examine this, we used the plasmid nicking assay which is an extremely sensitive method for detecting DNA strand breakage [29]. Incubation of increasing concentrations of BMAA following nitrosation with supercoiled plasmid DNA induced a linear increase in the amount of relaxed plasmid, demonstrating the formation of DNA single strand breaks (Figure 2). BMAA at the same concentrations also induced plasmid nicking but at lower levels (Figure 2) a result consistent with the observation that BMAA induced cellular DNA damage detectable by the alkaline comet assay [30]. Incubation of $\mathrm{N}$-alanine and alanine with plasmid DNA did not produce DNA nicks above those observed in controls under the conditions used. There was thus a clear difference between N-BMAA and $\mathrm{N}$-alanine induced plasmid DNA strand break formation, in contrast to previous reports indicating that BMAA and alanine themselves were of similar toxicity in a number of cell lines: a result that was taken to indicate that BMAA did not contribute significantly to human neurodegenerative disease [31]. 
We finally examined whether N-BMAA is cytotoxic to SH-SY5Y cells. SH-SY5Y is an immortalised neuroblastoma cell line with many of the characteristics of neuronal cells. It is used commonly for investigations of BMAA induced neuronal toxicity and in other studies relating to $A D, A L S$, and ALS/PDC [32-34]. Under conditions in which BMAA showed minimal toxicity, $N$-BMAA was toxic (Figure 3) and the differences were statistically significant at all time points $(p<0.05)$. $N$-BMAA toxicity was comparable to that of the positive control $(5 \mathrm{M} \mathrm{NaCl})$ and was maintained over the $96 \mathrm{hr}$ of the experiment except for the lowest doses for which toxicity appeared to accumulate over this time period.

We have not directly quantified the reactive alkylating species in this study and so do not know its level of formation from BMAA nitrosation. BMAA contains both a primary amine and a secondary amine that are potentially nitrosatable [35]. Nitrosation of the secondary amine will lead to a nitrosamine that typically requires metabolic activation to be reactive [36] whereas nitrosation of the primary amine results in a direct acting alkylating species that is the corresponding lactone [23]. It is thus possible that the observed activity in vitro results from the nitrosation of the primary amine but we cannot rule out the involvement of a nitrosamine in the cellular toxicity. The biological potency of alkylating agents results in a large part from the formation of DNA adducts $[22,37]$ and hence it is likely that the cytotoxicity induced by nitrosated BMAA results from this mechanism although we cannot as yet rule out other mechanisms.

In summary, these results are consistent with our hypothesis that chemical nitrosation of BMAA to $\mathrm{N}$-BMAA results in the formation of an alkylating agent. Furthermore, we have shown that $\mathrm{N}$-BMAA is more toxic than BMAA itself. Previously, methylazoxymethanol (MAM), which is also present in the cycad nut [20], was shown to be a classical alkylating agent causing toxic DNA damage (e.g. $O^{6}$ - 
methylguanine) in target cells [38] resulting in changes in cell-signalling gene expression pathways associated with human neurodegenerative disease [39]. The chemical structure of $N$-BMAA predicts that it will cause the same spectrum of DNA damage as that induced by MAM and other alkylating agents [40]. Analogously, $\mathrm{N}$-nitrosation of glycine results in both methylating and carboxymethylating agents that can generate the DNA adducts, $O^{6}$-methylguanine and $O^{6}$ carboxymethylguanine respectively [41]: both of these adducts have been detected in human DNA [42,43]. In addition to dietary BMAA sources, BMAA may also be generated in situ within the gastrointestinal lumen as a result of cyanobacteria $[44,45]$ which when coupled with heme-catalysed $\mathrm{N}$ nitrosation [46] may give rise to the formation of $N$-BMAA. These findings suggest a novel pathway of human exposure to potentially neurotoxic alkylating agents.

\section{Conclusions}

These results demonstrate that $\mathrm{N}$-nitrosation of BMAA results in an alkylating agent that damages DNA in vitro, generating single strand breaks, and is toxic to neuroblastoma cells. Our results suggest a novel hypothesis in which in situ nitrosation of BMAA, and potentially other amines, likely catalysed by the microbiome leads to the formation of a variety of alkylating agents that may contribute to the aetiology of ALS and other neurodegenerative diseases.

\section{Competing interests}

The authors declare that they have no competing interests.

\section{Author's contributions}

AP, GM, GP, PD designed experiments and analysed the data. GP performed assays. AP drafted the manuscript and all authors edited and reviewed the manuscript. 


\section{Acknowledgements}

The authors wish to thank Professor Doig (University of Manchester) for the gift of the SH-SY5Y cells.

\section{References}

1. Reed DM, Brody JA. Amyotrophic Lateral Sclerosis and Parkinsonism-Dementia on Guam, 19451972, Am. J. Epidemiol. 1975;101:287-301.

2. Bradley WG, Mash DC. Beyond Guam: the cyanobacteria/BMAA hypothesis of the cause of ALS and other neurodegenerative diseases, Amyotroph. Lateral Scler. 2009;10:7-20.

3. Cox PA, Banack SA, Murch SJ. Biomagnification of cyanobacterial neurotoxins and neurodegenerative disease among the Chamorro people of Guam, Proc. Natl. Acad. Sci. USA 2003;100:13380-3.

4. Plato CC, Garruto RM, Galasko D, Craig U-K, Plato M, Gamst A, et al. Amyotrophic lateral sclerosis and Parkinsonism-Dementia Complex of Guam: changing incidence rates during the past 60 years, Am. J. Epidemiol. 2003;157: 149-57.

5. Cox PA, Banack SA, Murch SJ, Rasmussen U, Tien G, Bidiqare RR et al. Diverse taxa of cyanobacteria produce beta-N-methylamino-L-alanine, a neurotoxic amino acid, Proc. Natl. Acad. Sci. USA 2005; 102:5074-8.

6. Faassen EJ. Presence of the Neurotoxin BMAA in Aquatic Ecosystems: What do we really know? Toxins 2014;6:1109-1138.

7. Murch SJ, Cox PA, Banack SA, Steele JC, Sacks OW. Occurrence of beta-methylamino-I-alanine (BMAA) in ALS/PDC patients from Guam. Acta Neurol. Scand. 2004;110:267-9. 
8. Pablo J, Banack SA, Cox PA, Johnson TE, Papapetropoulos S, Bradley WG et al. Cyanobacterial neurotoxin BMAA in ALS and Alzheimer's disease, Acta Neurol. Scand. 2009;120:216-25.

9. Chiu AS, Gehringer MM, Welch JH, Neilau BA. Does ?-amino-?-methylaminpropionic acid (BMAA) play a role in neurodegeneration, Int. J. Environ. Res. Public Health 2011;8:3728-46.

10. Lobner D. Mechanisms of beta-N-methylamino-L-alanine induced neurotoxicity, Amyotroph. Lateral Scler. 2009;10 Suppl 2: 56-60.

11. Dunlop RA, Cox PA, Banack SA, Rodgers KJ. The non-protein amino acid BMAA is incorporated into human proteins in place of L-serine causing protein misfolding and aggregation, PLoS One 2013;8:e75376.

12. van Onselen $R$, Cook NA, Phelan RR, Downing TG. Bacteria do not incorporate $\beta-N-$ methylamino-L-alanine into their proteins, Toxicon 2015;102:55-61.

13. Spencer PS, Garner CE, Palmer VS, Kisby GE. Vervets and macaques: similarities and differences in their responses to L-BMAA. NeuroToxciology 2016;56:284-286.

14. Rodgers KJ. Non-protein amino acids and neurodegeneration: the enemy within, Exp. Neurol. 2014;253:192-6.

15. Murch SJ, Cox PA, Banack SA. A mechanism for slow release of biomagnified cyanobacterial neurotoxins and neurodegenerative disease in Guam, Proc. Natl. Acad. Sci. USA 2004;101: 12228-31.

16. Karamyan VT, Speth RC. Animal models of BMAA neurotoxicity: A critical review, Life Sci. 2008; 82:233-46.

17. de Munck E1, Muñoz-Sáez E, Miguel BG, Solas MT, Ojeda I, Martínez A, et al. $\beta$-N-methylaminoI-alanine causes neurological and pathological phenotypes mimicking Amyotrophic Lateral 
Sclerosis (ALS): the first step towards an experimental model for sporadic ALS. Environ Toxicol Pharmacol. 2013 ;36:243-55.

18. Spencer PS, Nunn PB, Hugon J, Ludolph AC, Ross SM, Roy DN, Robertson RC. Guam Amyotrophic lateral sclerosis-Parkinsonism-Dementia linked to a plant excitant neurotoxin. Science 1987;237:517-522.

19. Duncan M. B-methylamino-I-alanine (BMAA) and Amyotrophic lateral sclerosis-ParkinsonismDementia of the Western Pacific. Ann NY Acad Sci. 1992;161-168.

20. Kisby GE, Olivas A, Park Y, Churchwell M, Doerge D, Samson LD et al. DNA repair modulates the vulnerability of the developing brain to alkylating agents, DNA Repair 2009; 8:400-12.

21. Kisby GE, Moore H, Spencer PS. Animal models of brain maldevelopment induced by cycad plant genotoxins, Birth Defects Res. C Embryo Today 2013;99:247-55.

22. Kaina B, Christmann M, Naumann S, Roos WP. MGMT: key node in the battle against genotoxicity, carcinogenicity and apoptosis induced by alkylating agents, DNA Repair 2007;6:1079-99.

23. Garcia-Santos MedIP, Calle E, Casado J. Amino acid nitrosation products as alkylating agents, J. Am.Chem.Soc. 2001;123:7506-10.

24. Shephard SE, Meier I, Lutz WK. Alkylating potency of nitrosated amino acids and peptides , IARC Sci. Publ. 1991;105:383-7.

25. Shephard SE, Hegi ME, Lutz WK. In-vitro assays to detect alkylating and mutagenic activities of dietary components nitrosated in situ. IARC Sci. Publ. 1987;84:232-6.

26. Thomas JJ, Kim JH, Mauro DM. 4-(4-Nitrobenzyl)pyridine tests for alkylating agents following chemical oxidative activation Arch. Environ. Contam.Toxicol. 1992;22:219-27. 
27. Gomez-Bomberelli R, Gonzalez-Perez M, Calle E, Casado J. Potential of the NBP method for the study of alkylation mechanisms: NBP as a DNA-model, Chem. Res. Toxicol. 2012;25:1176-91.

28. Boysen G, Pachkowski BF , Nakamura J, Swenberg JA. The formation and biological significance of N7-guanine adducts, Mutat. Res. 2009;678:76-94

29. Dumax-Vorzet AF, tate M, Walsmley R, Elder RH, Povey AC. Cytotoxicity and genotoxicity of urban particulate matter in mammalian cells, Mutagenesis 2015;30:621-3.

30. Chiu AS, Gehringer MM, Braidy N, Guillemin GJ, Welch JH, Neilan BA. Excitotoxic potential of the cyanotoxin ?-methyl-amino-L-alanine (BMAA) in primary human neurons, Toxicon 2012;60:1159-65.

31. Lee M, McGeer PL. Weak BMAA toxicity compares with that of the dietary supplement betaalanine, Neurobiol. Aging 2012;33:1440-7.

32. Lopes FM, Schroder R, da Frota ML Jr, Zanotto-Filho A, Muller CB, Pires AS et al. Comparison between proliferative and neuron-like SH-SY5Y cells as an in vitro model for Parkinson disease studies, Brain Res. 2010; 1337:85-94.

33. Kovalevich J, Langford D. Considerations for the use of SH-SY5Y neuroblastoma cells in neurobiology, Methods Mol. Biol. 2013;1078:9-21.

34. Okle O, Stemmer K, Deschi U, Dietrich DR. L-BMAA induced ER stress and enhanced caspase 12 cleavage in human neuroblastoma SH-SY5Y cells at low nonexcitotoxic concentrations, Toxicol. Sci. 2013;131:217-24.

35. Rostkowska K, Zwierz K, Rozanski A, Moniuszko-Jakoniuck J, Roszczenko A. Formation and metabolism of N-nitrosamines. Pol. J. Environ. Stud. 1998; 7:321-325. 
36. Hecht SS. Metabolic activation and detoxification of tobacco-specific nitrosamines - a model for cancer prevention studies. Drug Metab. Rev. 1994;26:373-390.

37. Drabløs F, Feyzi E, Aas PA, Vaagbø CB, Kavli B, Bratlie MS, et al. Alkylation damage in DNA and RNA--repair mechanisms and medical significance. DNA Repair (Amst). 2004; 3:1389-407.

38. Esclaire F, Kisby G, Spencer P, Milne J, Lesort M, Hugon J. The Guam cycad toxin methylazoxymethanol damages neuronal DNA and modulates tau mRNA expression and excitotoxicity, Exp. Neurol. 1999;155:11-21.

39. Kisby GE, Fry RC, Lasarev MR, Bammler TK, Beyer RP, Churchwell M, et al. The cycad genotoxin MAM modulates brain cellular pathways in neurodegenerative disease and cancer in a DNA damage-linked manner, PLoS ONE 2011;6:e20911

40. Beranek DT, Weis CC, Swenson DH. A comprehensive quantitative-analysis of methylated and ethylated DNA using high-pressure liquid-chromatography, Carcinogenesis 1980; 7:595-606.

41. Harrison KL, Jukes R, Cooper DP, Shuker DE. Detection of concomitant formation of $O^{6}$ carboxymethyl- and $O^{6}$-methyl-2'-deoxyguanosine in DNA exposed to nitrosated glycine derivatives using a combined immunoaffinity/HPLC method, Chem. Res. Toxicol. 1999;12:10611.

42. Povey AC, Hall CN, Badawi AF, Cooper DP, O'Connor PJ. Elevated levels of the pro-carcinogenic adduct $O^{6}$-methylguanine in normal DNA from the cancer prone regions of the large bowel, Gut $2000 ; 47: 362-5$.

43. Lewin MH, Bailey N, Bandaletova T, Bowman R, Cross AJ, Pollock J, et al. Red meat enhances the colonic formation of the DNA adduct $O^{6}$-carboxymethyl guanine: implications for colorectal cancer risk, Cancer Res. 2006;66:1859-65. 
44. Ley RE, Peterson DA, Gordon JI. Ecological and evolutionary forces shaping microbial diversity in the human intestine, Cell 2006; 124:837-48.

45. Hill JM, Bhattacharjee S, Pogue Al, Lukiw WJ. The gastrointestinal tract microbiome and potential link to Alzheimer's disease, Front. Neurol. 2014;5:43

46. Lunn JC, Kuhnle G, Mai V, Frankenfeld C, Shuker DE, Glen RC et al. The effect of haem in red and processed meat on the endogenous formation of $\mathrm{N}$-nitroso compounds in the upper gastrointestinal tract, Carcinogenesis 2007;28:685-90. 
Figure 1. Detection of alkylating intermediates formed by nitrosation of BMAA and Alanine using the NBP trapping assay.

Varying concentrations of BMAA or alanine $(\boldsymbol{\Delta}-\mathbf{\Delta})$ were simultaneously incubated with $\mathrm{NaNO}_{2}, \mathrm{NBP}$, and citrate buffer, the colour development reagent added and absorbance measured at $595 \mathrm{~nm}$. Absorbance of negative controls (see text) was less than 0.05 .

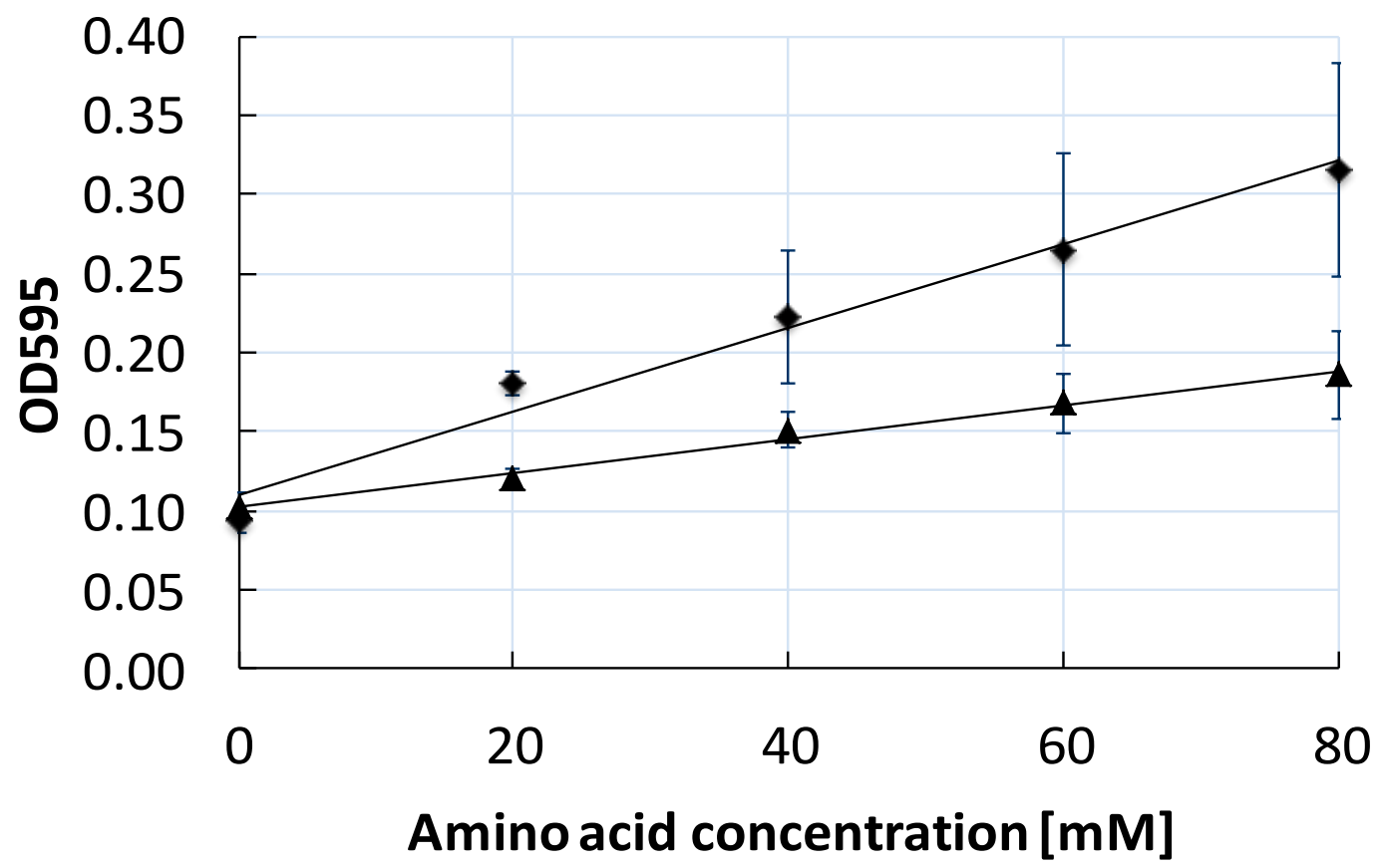

Figure 2. $N$-BMAA and BMAA in the plasmid nicking assay

$\mathrm{N}$-BMAA, prepared by chemically nitrosating BMAA with $\mathrm{NaNO}_{2}$ in citrate buffer, and BMAA were incubated with supercoiled pchAT plasmid DNA and the samples electrophoresed on an agarose gel containing GelRed fluoresecent DNA stain. Gels were scanned using a Typhoon Phosphorimager using Alexa fluorescence settings and ImageJ software was used to quantify the relative amounts of supercoiled and nicked plasmid.

Panel A N-BMAA gel; Panel B BMAA ; Panel C Controls: buffer (neg), $25 \mu \mathrm{M} \mathrm{FeSO} / 3 \mathrm{mM} \mathrm{H}_{2} \mathrm{O}_{2}$ (pos), $4 \mathrm{mM} \mathrm{NaNO}_{2}$; Panel $\mathrm{D}$ Shows Image J results of relative amounts of nicked and supercoiled plasmid 
plotted against the BMAA concentration ( $-\square)$ or the BMAA concentration in the initial nitrosation mix for $N$-BMAA $(-$ ). Alanine and $N$-nitrosated alanine did not cause any plasmid nicking (results not shown)

\section{A: N-BMAA}
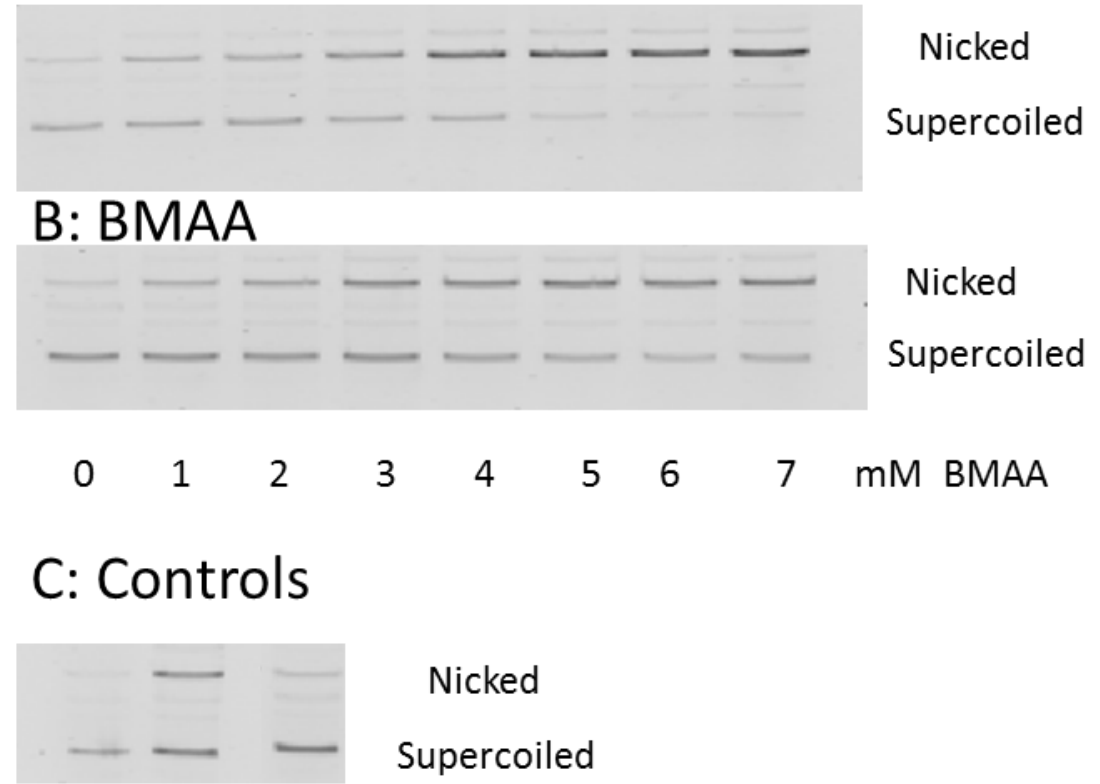

Nicked

Supercoiled

Neg Pos $\mathrm{NaNO}_{2}$

D: Image J quantitation

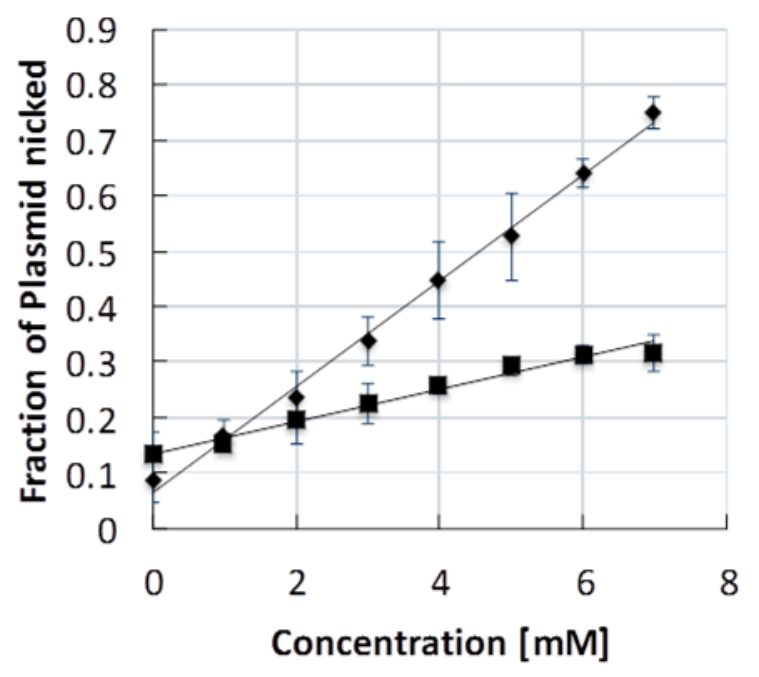


Figure 3. Cell viability of SH-SY5Y cells following treatment with $N$-BMAA and BMAA

SH-SY5Y cells were incubated with BMAA (panel A) and N-BMAA (panel B) prepared by nitrosating BMAA with $\mathrm{NaNO}_{2}$ in citrate buffer. Cell viability was assessed using resazurin and fluorescence was quantified with an excitation wavelength at 540nm and emission at 590nm using a TECAN infiniti M200 Pro. The positive control for cytotoxicity was $\mathrm{NaCl}$ and the negative solvent control is identified as S.C. N-BMAA concentrations refer to the BMAA concentration in the initial nitrosation mix. Significant differences between $N$-BMAA treatments and solvent control observed at all time points $(p<0.05)$. the nitrosation mix $\left(\mathrm{NaNO}_{2} /\right.$ citrate) was not toxic (data not shown) 


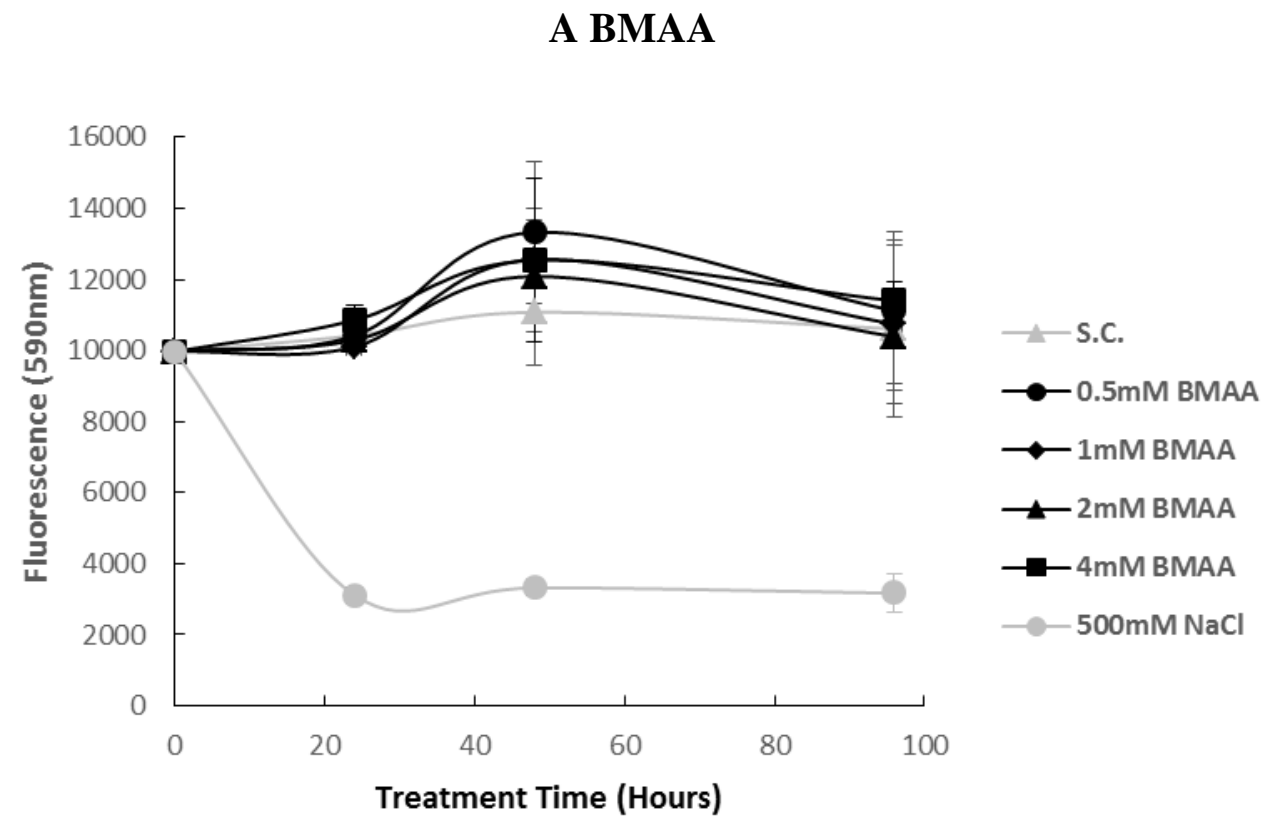

\section{B $N$-BMAA}

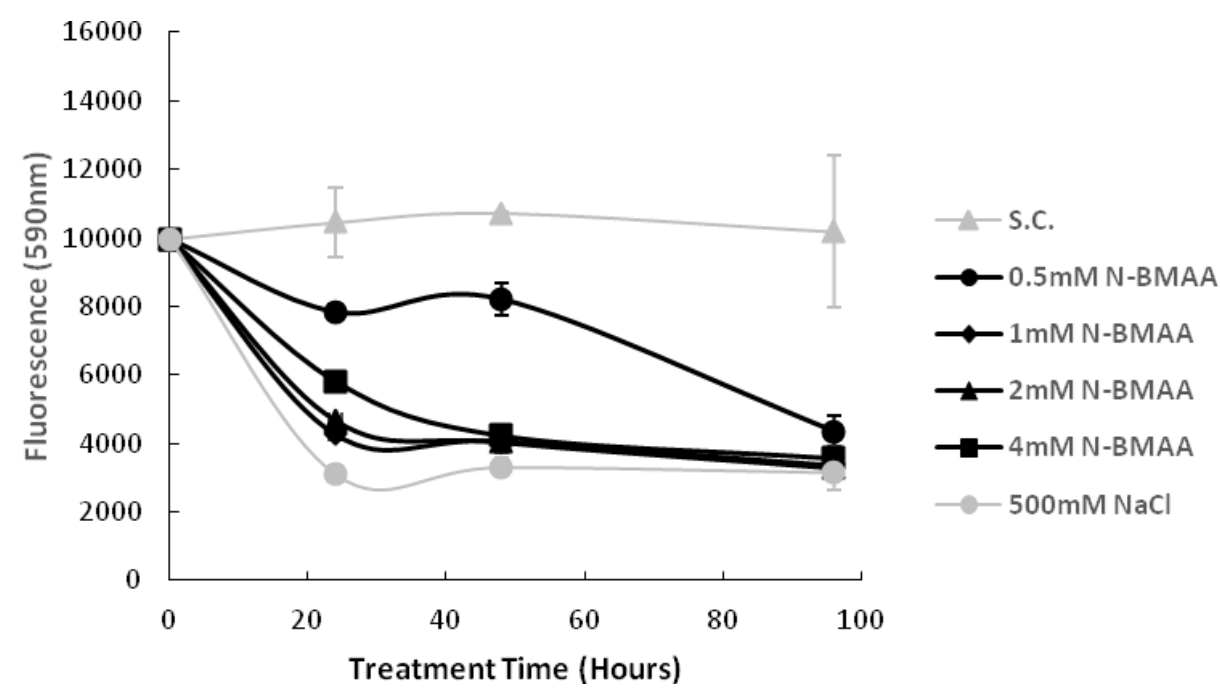

